improve during a pregnancy than to relapse. But after delivery relapse of bowel symptoms is common, confirming a trend indicated by Fielding and Cooke (1970). Indeed, on conservative management alone such a relapse is the rule rather than the exception.

\section{MANAGEMENT OF PREGNANCY IN PATIENTS WITH CROHN'S DISEASE}

From previous work and from the present study an overall pattern emerges which enables some broad recommendations to be made about the management of such patients. Firstly, one must expect a proportion of women with Crohn's disease to be subfertile, though experience indicates that this is more likely to be related to the activity of the bowel complaint than any permanent anatomical lesion. Next, patients who inquire about the dangers of pregnancy in Crohn's disease may be broadly reassured; and certainly there is no ground whatsoever for regarding Crohn's disease as an indication for termination of pregnancy or sterilization. During pregancy itself one may expect that the symptoms of Crohn's disease will either remain static or even improve, though patients should be carefully followed up for at least three months after delivery, since a high proportion will experience a relapse of symptoms at this time.

As regards the details of such postpartum management the indications for surgery have been dealt with elsewhere but in the present context it is worth noting that this may be the one situation where steroids may be of value in the management of Crohn's disease. Following our earlier similar findings in a survey of 465 patients with ulcerative colitis (de Dombal et al., 1965) we carried out a small-scale trial and were able to link in one or two cases a relapse of symptoms with a sharp drop in the level of serum cortisol (de Dombal, 1966). It would thus seem logical to try the effects of systemic corticosteroid therapy in this comparable situation vis-à-vis. Crohn's disease.

We are grateful to the physicians and surgeons of the Leeds General Infirmary for permission to study patients with Crohn's disease admitted under their care. One of us (I.L.B.) was supported by a grant from the board of governors of the United Leeds Hospitals, which we also acknowledge with gratitude.

\section{References}

Baird, D. (1950). In Combined Textbook of Obstetrics and Gynaecology for Students and Practitioners. Edinburgh, Livingstone.

Barnes, C. S., and Hayes, H. M. (1931). American Fournal of Obstetrics and Gynecology, 22, 907 .

Blair, J. S. G., and Allen, N. (1962). Fournal of Obstetrics and Gynaecology of the British Commonwealth, 69, 648 .

Boreham, P. F., and Saltau, D. H. K. (1970). British Medical fournal, 2, 541. Crohn, B. B., Yarnis, H., and Korelitz, B. I. (1956). Gastroenterology, 31, 615. de Dombal, F. T. (1966). Unpublished observations.

de Dombal, F. T. (1972). Unpublished data.

de Dombal, F. T., Watts, J. McK., Watkinson, G., and Goligher, J. C. Dombal, F. T., Watts,
(1965). Lancet, 2, 599.

de Dombal, F. T., Burton, I. L., and Goligher, J. C. (1971). British fournal

Fielding, J. F., and Cooke, W. T. (1970). British Medical fournal, 2, 76.

Howkins, J. (1962). In Shaw's Textbook of Gynaecology, 8th ed. London, Churchill.

Heyworth, B., Basu, S., and Clegg, J. (1970). British Medical fournal, 2, 364.
Imrie, A. H. (1970). British Medical fournal, 2, 299.

Jones, S. R. L., and Saltau, D. H. K. (1958). Fournal of Obstetrics and Gynaecology of the British Empire, 65, 811.

Morson, B. C. (1968). In Ulcerative Colitis, by J. C. Goligher, F. T. de Dombal, J. M. Watts, and G. Watkinson. London, Baillière Tindall and Cassell.

Schofield, P. F., Turnbull, R. B., and Hawk, W. A. (1970). British Medical fournal, 2, 364.

\title{
Influenza and Infant Mortality
}

\section{G. WYNNE GRIFFITH, A. M. ADELSTEIN, P. M. LAMBERT, J. A. C. WEATHERALL}

British Medical fournal, 1972, 3, 553-556

\section{Summary}

Early neonatal mortality in England and Wales in the second quarter of 1970 after a major influenza epidemic was slightly but significantly higher than in the corresponding quarter of the previous year. An increase was also noted in the first quarter of 1970 . Analysis of infant mortality and an index of influenza prevalence over the past quarter-century indicates that similar increases occurred in relation to four of the other five major influenza epidemics during the period, the exception being the "Asian 'flu" epidemic of the autumn of 1957. It is suggested that the increased mortality in 1970 was the consequence of an increase in the prematurity rate, but we have no evidence to indicate whether the effect is specifically due to the virus or is nonspecific in nature.

\section{Introduction}

In his annual report for 1970 the chief medical officer of the Department of Health and Social Security noted that infant

Department of Health and Social Security, London S.E.1 G. WYNNE GRIFFITH, M.D., D.P.H., Principal Medical Officer Office of Population Censuses and Surveys, London W.C.2 A. M. ADELSTEIN, M.D., D.P.H., Chief Medical Statistician
P. M. LAMBERT, M.B., D.P.H., Senior Medical Officer J. A. C. WEATHERALL, M.B., B.sC., Senior Medical Officer mortality had increased in comparison with the previous year; this was remarkable as only once previously, in 1951, had such an increase occurred in the past 25 years. As in 1951, it was the neonatal death rate that was most affected in 1970, and Sir George Godber pointed out that both 1951 and 1970 were years when a major epidemic of influenza had occurred. It had been suggested in the past that maternal influenza could give rise to congenital abnormalities but, he concluded, an association had not been clearly proved. Nevertheless, the coincidence linking the infant mortality rates of 1951 and 1970 merited further investigation (Department of Health and Social Security, 1971).

In this paper we analyse data for England and Wales derived from the Registrar General's annual reviews and quarterly returns. We also discuss mortality data from the official records of certain other countries and records of birth weight from a number of local health authorities.

\section{England and Wales 1969 and 1970}

Comparison of the infant mortality rates for 1969 and 1970 shows that only the early neonatal death rate increased in 1970 , from 10.33 to 10.61 per 1,000 live births. The stillbirth rate and late neonatal and postneonatal death rates in 1970 were all lower than in the previous year. Furthermore, this increase in the early neonatal rate occurred predominantly in the second (June) quarter (from 9.88 per 1,000 live births in 1969 to 10.77 in 1970), although there was also a rise (from $10 \cdot 26$ per 1,000 to $10.56)$ in the rate for the first (March) quarter. 
The death rates from certain causes in the early neonatal period for the second quarters of 1969 and 1970 are set out in Table I. In both periods the two most important categories of causes were anoxic and hypoxic conditions (I.C.D. 776) and immaturity, unqualified (I.C.D. 777). These are, of course,

TABLE I-Early Neonatal Deaths from Certain Causes per 1,000 Live Births in England and Wales in the fune Quarters of 1969 and 1970

\begin{tabular}{|c|c|c|c|}
\hline Cause (I.C.D. Categories) & & 1969 & 1970 \\
\hline 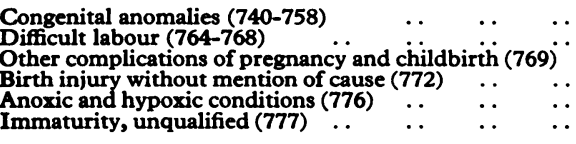 & $\begin{array}{l}\cdots \\
\because \\
\cdots \\
\cdots\end{array}$ & $\begin{array}{l}1.51 \\
0.18 \\
0.71 \\
0.90 \\
2.97 \\
1.75\end{array}$ & $\begin{array}{l}1.51 \\
0.10 \\
0.79 \\
0.99 \\
3.42 \\
1.96\end{array}$ \\
\hline
\end{tabular}

(Source: Registrar General's Statistical Review of England and Wales, Part 1, 1969 and 1970, Table 23C.)

closely related clinically in that the conditions listed under I.C.D. 776 (hyaline membrane disease, respiratory distress syndrome, and anoxia of the newborn) affect almost exclusively infants born before term and are probably the cause of the majority of deaths of such infants even when certified as due to immaturity or prematurity. The death rates due to both these categories were substantially higher in the second quarter of 1970 than in the corresponding quarter of the previous year and together account for most of the disparity between the periods in the total rate. Smaller increases also occurred in the rates for two other categories, I.C.D. 769 (other complications of pregnancy and childbirth) and I.C.D. 772 (birth injury, without mention of cause), both of which are clinically closely allied to immaturity. There was no increase in the death rate attributed to congenital anomalies (I.C.D. 740-758).

\section{Previous Statistics}

If the influenza epidemic of the winter of 1970 adversely affected the early neonatal mortality in the first and, more particularly, the second quarters of that year one might expect to find that previous large influenza epidemics had exerted a similar effect. Influenza epidemics are common in England and Wales and the virus is circulating more or less widely in the population almost every winter. It is possible, however, to recognize five major epidemics which occurred in the winter months during the period from 1948 to 1971 . These were in 1951, 1953, 1959, 1961, and 1970.

During the first quarters of each of these five years more than 5,500 deaths from influenza were registered in England and Wales. These years are designated for our present purposes as "epidemic" years. The quarterly stillbirth rates and early and late neonatal death rates for each of the epidemic years and for the immediately preceding years are set out in Table II. The data are summarized in terms of the mean differences by quarters for each of the three indices of mortality in Table III. Since all three rates tended to decline over the period in question a negative value for the mean difference between pairs of consecutive years was to be expected, and this was so for each of the quarters for the stillbirth rate and the late neonatal death rate. In contrast, for early neonatal deaths there was evidently a difference between the first and second quarters on the one hand and the third and fourth quarters on the other. Whereas in the former half-years the mean differences were positive, in the second halves of the years the mean differences, in keeping with an overall trend downward, were negative.

An analysis of variance of the data in Table II shows that the early neonatal death rates in the first half of the year differ significantly $(P<0.01)$ from the rates in the second half of the year when epidemic years are compared with the years immediately preceding. No similar significant differences appear for the stillbirth and the late neonatal death rates.

During this same period there were six years $(1948,1957$, $1960,1965,1967$, and 1971) when fewer than 550 deaths from
TABLE II-Stillbirth and Neonatal Mortality by Quarters, Comparing Rates for Each Epidemic Year with those for the Immediately Preceding Year England and Wales 1950-70

\begin{tabular}{|c|c|c|c|c|c|c|c|}
\hline \multicolumn{4}{|c|}{ Quarter ending: } & March & June & September & Decembe \\
\hline \multicolumn{8}{|c|}{ Stillbirths (per 1.000 Births) } \\
\hline $\begin{array}{l}1950 \\
1951\end{array}$ & $\because$. & $\because$. & 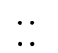 & $\begin{array}{l}22.99 \\
23.15\end{array}$ & $\begin{array}{l}22.49 \\
22.58\end{array}$ & $\begin{array}{l}22.52 \\
21.84\end{array}$ & $\begin{array}{l}22 \cdot 73 \\
24 \cdot 16\end{array}$ \\
\hline $\begin{array}{l}1952 \\
1953\end{array}$ & $\because$. & 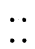 & 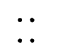 & $\begin{array}{l}23.51 \\
22.63\end{array}$ & $\begin{array}{l}22.47 \\
22.97\end{array}$ & $\begin{array}{l}21.63 \\
21.01\end{array}$ & $\begin{array}{l}23 \cdot 25 \\
23 \cdot 36\end{array}$ \\
\hline $\begin{array}{l}1958 \\
1959\end{array}$ & $\because$. & 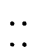 & $\because$. & $\begin{array}{l}21.61 \\
21.41\end{array}$ & $\begin{array}{l}20.93 \\
21.04\end{array}$ & $\begin{array}{l}21.67 \\
20 \cdot 45\end{array}$ & $\begin{array}{l}21.88 \\
20.25\end{array}$ \\
\hline $\begin{array}{l}1960 \\
1961\end{array}$ & . & . & . & 19.92 & $\begin{array}{l}20 \cdot 14 \\
18 \cdot 27\end{array}$ & $\begin{array}{r}19 \cdot 29 \\
18.50\end{array}$ & $\begin{array}{l}19.65 \\
20.04\end{array}$ \\
\hline $\begin{array}{l}1969 \\
1970\end{array}$ & . & . & . & $\begin{array}{l}13.43 \\
13.18\end{array}$ & 12.73 & $\begin{array}{l}12 \cdot 81 \\
12.72\end{array}$ & $\begin{array}{l}13.81 \\
13.39\end{array}$ \\
\hline \multicolumn{8}{|c|}{ Early Neonatal Deaths (per 1,000 Live Births) } \\
\hline $\begin{array}{l}1950 \\
1951\end{array}$ & $\because$ & $\because$. & $\therefore$ & $\begin{array}{l}15 \cdot 85 \\
16.25\end{array}$ & $\begin{array}{l}15.03 \\
15.41\end{array}$ & $\begin{array}{l}14.42 \\
13.99\end{array}$ & $\begin{array}{l}16.06 \\
16.18\end{array}$ \\
\hline $\begin{array}{l}1952 \\
1953\end{array}$ & $\because$. & 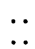 & $\because$. & $\begin{array}{l}15.59 \\
15.80\end{array}$ & $\begin{array}{l}14.63 \\
14.85\end{array}$ & $\begin{array}{l}14.36 \\
14.00\end{array}$ & $\begin{array}{l}16.06 \\
14.75\end{array}$ \\
\hline $\begin{array}{l}1958 \\
1959\end{array}$ & $\because$ & $\because$ & $\because$. & $\begin{array}{l}13.68 \\
13.59\end{array}$ & $\begin{array}{l}13.62 \\
13.56\end{array}$ & $\begin{array}{l}13.74 \\
12.95\end{array}$ & $\begin{array}{l}14 \cdot 13 \\
14 \cdot 29\end{array}$ \\
\hline $\begin{array}{l}1960 \\
1961\end{array}$ & $\because$ & $\because$ & $\because$ & $\begin{array}{l}13.46 \\
13.59\end{array}$ & $\begin{array}{l}12.85 \\
13.25\end{array}$ & $\begin{array}{l}13.13 \\
12.63\end{array}$ & $\begin{array}{l}13.96 \\
13.65\end{array}$ \\
\hline 1969 & . & .. & . & $10 \cdot 26$ & $9 \cdot 88$ & $10 \cdot 27$ & 10.96 \\
\hline 1970 & .. & .. & .. & 10.56 & $10 \cdot 77$ & $10 \cdot 37$ & 10.75 \\
\hline \multicolumn{8}{|c|}{ Late Neonatal Deaths (per 1,000 Live Births) } \\
\hline $\begin{array}{l}1950 \\
1951\end{array}$ & .. & $\therefore$ & 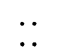 & $\begin{array}{l}4 \cdot 11 \\
4 \cdot 35\end{array}$ & $\begin{array}{l}3.08 \\
3.08\end{array}$ & $\begin{array}{l}2.59 \\
2.86\end{array}$ & $\begin{array}{l}3.56 \\
3.12\end{array}$ \\
\hline $\begin{array}{l}1952 \\
1953\end{array}$ & .. & $\therefore$ & $\therefore$ & $\begin{array}{l}3.94 \\
3.70\end{array}$ & $\begin{array}{l}2.76 \\
2.68\end{array}$ & $\begin{array}{l}2 \cdot 64 \\
2 \cdot 37\end{array}$ & $\begin{array}{l}3.33 \\
2.75\end{array}$ \\
\hline $\begin{array}{l}1958 \\
1959\end{array}$ & .. & .. & $\therefore$ & $\begin{array}{l}2.82 \\
2.73\end{array}$ & $\begin{array}{l}2.39 \\
2.07\end{array}$ & $\begin{array}{l}2.09 \\
2.09\end{array}$ & $\begin{array}{l}2 \cdot 16 \\
2 \cdot 24\end{array}$ \\
\hline $\begin{array}{l}1960 \\
1961\end{array}$ & $\because$ & $\therefore$ & $\because$ & $\begin{array}{l}2.51 \\
2.30\end{array}$ & $\begin{array}{l}2.11 \\
1.88\end{array}$ & $\begin{array}{l}1.92 \\
1.93\end{array}$ & $\begin{array}{l}2 \cdot 23 \\
2 \cdot 15\end{array}$ \\
\hline $\begin{array}{l}1969 \\
1970\end{array}$ & .. & $\ldots$ & 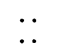 & $\begin{array}{l}1.79 \\
1.75\end{array}$ & $\begin{array}{l}1.70 \\
1.56\end{array}$ & $\begin{array}{l}1.62 \\
1.58\end{array}$ & $\begin{array}{l}1.72 \\
1.93\end{array}$ \\
\hline
\end{tabular}

(Source: Registrar General's Quarterly Return for England and Wales, Table 1a.)

TABLE III-Mean Difference between Rates in Epidemic Years and Preceding Years by Quarters

\begin{tabular}{|c|c|c|c|c|}
\hline Quarter ending: & March & June & September & December \\
\hline $\begin{array}{l}\text { Stillbirths (per } 1,000 \text { births) } \\
\text { Early neonatal deaths (per } 1,000\end{array}$ & -0.356 & $-0 \cdot 222$ & -0.680 & -0.024 \\
\hline $\begin{array}{l}\text { live births) } \\
\text { a }\end{array}$ & $+0 \cdot 190$ & +0.366 & -0.396 & -0.310 \\
\hline $\begin{array}{c}\text { Late neonatal deaths (per } 1,000 \\
\text { live births) }\end{array}$ & -0.068 & -0.154 & -0.006 & -0.162 \\
\hline
\end{tabular}

influenza were registered in the first quarter-that is, there was at least a tenfold difference in influenza mortality between any one of these years and any of the epidemic years. These six years are referred to as "non-epidemic" years. The "trends" from 1948 to 1971 of the stillbirth rate and the early and late neonatal death rates in the first and second half-years in epidemic and non-epidemic years are shown in Fig. 1. Of the six comparisons only for the early neonatal death rate in the first half-year is the trend followed in the epidemic years distinct from that followed in the non-epidemic years. The trends in Fig. 1 do not, of course, correspond to any mathematical function, but a variety of curves have been fitted to the data for early neonatal mortality in the June quarters of the years 1948 to 1971 . Although a really well-fitting curve has not been found the observed rates for epidemic years exceed the calculated values whatever the type of function tried, while most of the observed rates for non-epidemic years are below the calculated values. For example, a Gompertz function gives a tolerable fit for the rates from 1951 to 1971 . The rates for all five epidemic years lie above the curve and those of four out of five non-epidemic years below it, an outcome unlikely to be due to chance (by Fisher's test, $P=0.024$ ).

\section{Statistics from Other Countries}

If the interpretation is correct the association of influenza epidemics with increases in early neonatal mortality should also appear in the statistics of other countries. On the evidence from England and Wales, however, the effect is a relatively small one, and large population groups would be necessary to provide reliable information. Data from the United States for the period 

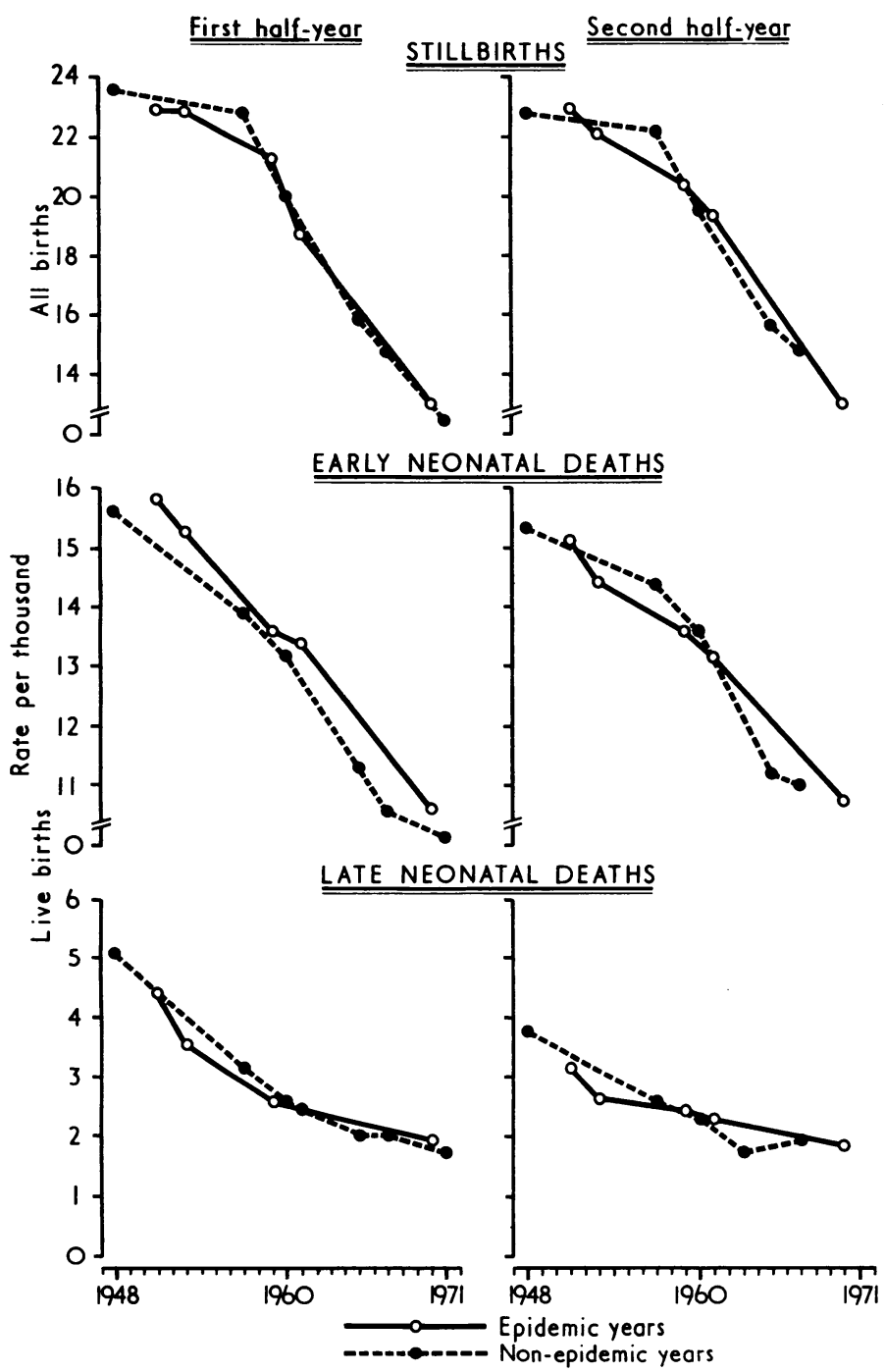

FIG. 1-Stillbirth and neonatal mortality rates during first and second half years in epidemic and non-epidemic years in England and Wales 1948-71.

1950-67-more recent data are not available-are presented in Fig. 2 in a similar manner to that adopted for the data from England and Wales. The pattern is similar to that for England and Wales although the magnitude of the effect is smaller. More recent figures from New York City offer further support for the hypothesis. New York City suffered a severe epidemic of influenza due to the A2 Hong Kong variant in the winter of 1968-9 -a year earlier than in Britain - with a substantial number of deaths. As shown in Table IV, apart from the second quarter of 1967 the first and second quarters of 1969 were the only ones to show any sharp reversal of the rapid decline in early neonatal mortality which had been occurring since 1965 .

We have not attempted an extensive inquiry into the experience of other countries. Material strictly comparable to that we have presented for England and Wales with respect to both influenza and early neonatal mortality by quarter-years is not generally available. Some of the data published by the World Health Organization are, however, suggestive. For instance, Austria and the Federal Republic of Germany experienced a major influenza epidemic in the winter of 1969-70, and their

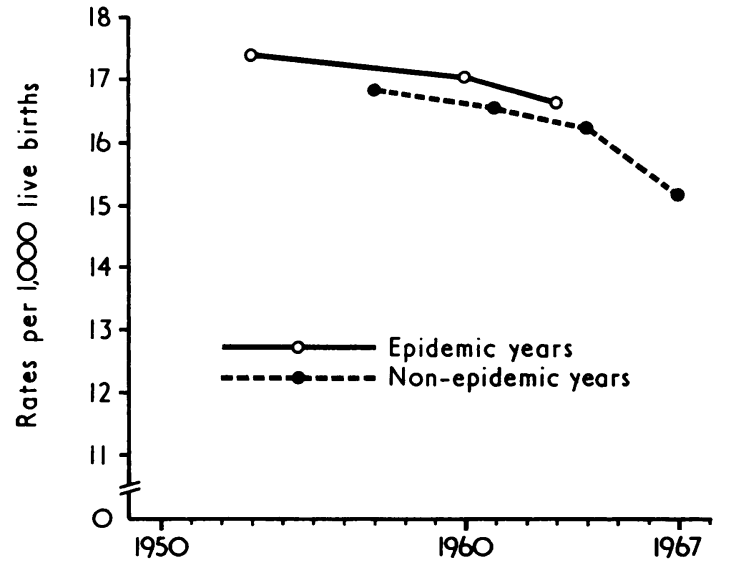

FIG. 2-Early neonatal mortality during first half-year in epidemic and non-epidemic years in the U.S.A. 1950-67.

neonatal death rates in the second quarter of 1970 were higher than in the corresponding quarter of 1969. In the Netherlands and in Scotland also the neonatal death rates were higher in the second quarter of 1970 than in that of 1969 , but as these rises were not the only ones to occur in recent years they may have been unrelated to the high influenza prevalence of early 1970 . Neonatal death rates in the Irish Republic and in Northern Ireland on the other hand were lower in the second quarter of 1970 than in the corresponding quarter of 1969 (World Health Organization, 1970, 1971). The experience of Poland is interesting in that both 1969 and 1970 saw very large influenza epidemics, with 4.5 and 3.9 million cases reported in the first quarters. The early neonatal death rates in the second quarters of these two years were higher than in the second quarter of either 1968 or 1971 (J. Kostrzewski, personal communication, 1971).

In summary, the data available from other countries offer some further support for the hypothesis that severe epidemics of influenza are followed by increased neonatal mortality.

\section{Discussion}

We believe that the evidence presented suggests that when influenza is widely prevalent early neonatal mortality is likely to be increased and that the effect is most pronounced in infants born some months after the peak of the epidemic (as measured by the mortality in the general population). For several reasons we do not think that the effect can be attributed to infection of the newborn acquired after birth. If that were indeed the mechanism one would not expect a major impact in the quarter following the epidemic prevalence and one would expect the late neonatal death rates to be adversely affected. Furthermore, one would have to postulate extremely fulminating infections because the tendency to an increased mortality in the second quarter of an epidemic year can be discerned even in the death rates of ages under 1 day.

The way in which the increase in mortality is mainly confined to the categories associated with prematurity (Table I) suggests two possible explanations. Firstly, it might be that a high community prevalence of influenza affecting pregnant mothers leads to an increased prematurity rate. Alternatively, the fatality rate among premature babies may be increased owing to some

TABLE IV-Deaths from Influenza and Pneumonia in First Quarter of Each Year, and Early Neonatal Mortality Rates per 1,000 Live Births in First and Second Quarters of Each Year; 1965 to 1971, in New York City (Health Centre Districts)

\begin{tabular}{|c|c|c|c|c|c|c|c|c|}
\hline & & 1965 & 1966 & 1967 & 1968 & 1969 & 1970 & 1971 \\
\hline $\begin{array}{l}\text { Deaths from influenza and pneumonia in first quarter } \ldots \\
\text { Early neonatal mortality rates per } 1,000 \text { live } \\
\text { births } \ldots \\
\begin{array}{l}\text {. } \\
\text { First quarter }\end{array} \\
\text { Second quarter }\end{array}$ & $\because$ & $\begin{array}{l}1,081 \\
19 \cdot 0 \\
17 \cdot 0\end{array}$ & $\begin{array}{l}1,037 \\
17 \cdot 0 \\
16 \cdot 7\end{array}$ & $\begin{array}{l}885 \\
16 \cdot 4 \\
17 \cdot 6\end{array}$ & $\begin{array}{l}1,258 \\
15 \cdot 8 \\
14 \cdot 4\end{array}$ & $\begin{array}{l}1,366 \\
16 \cdot 2 \\
15 \cdot 4\end{array}$ & $\begin{array}{l}1,184 \\
13 \cdot 9 \\
15 \cdot 3\end{array}$ & $\begin{array}{c}1,100 \\
13 \cdot 8 \\
9 \cdot 3^{*}\end{array}$ \\
\hline
\end{tabular}

*April figure only. 
TABLB V-Percentage of Liveborn Infants weighing less than $2,500 \mathrm{~g}$ in Several Local Health Authority Areas by Quarter-years 1969 and 1970

\begin{tabular}{|c|c|c|c|c|c|c|c|c|c|c|}
\hline \multicolumn{4}{|c|}{ Quarters Ending: } & \multirow{2}{*}{$\begin{array}{c}\text { Birmingham } \\
\begin{array}{c}8.92 \\
9.74\end{array}\end{array}$} & \multirow{2}{*}{$\begin{array}{c}\text { Cardiff } \\
\begin{array}{c}5 \cdot 71 \\
7 \cdot 78\end{array}\end{array}$} & \multirow{2}{*}{$\begin{array}{c}\text { Leicester } \\
9.29 \\
10.63\end{array}$} & \multirow{2}{*}{$\begin{array}{c}\text { Manchester } \\
\begin{array}{c}8.44 \\
9 \cdot 23\end{array}\end{array}$} & \multirow{2}{*}{ 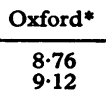 } & \multirow{2}{*}{$\begin{array}{c}\text { East Sussex } \\
\begin{array}{c}6.25 \\
5.71\end{array}\end{array}$} & \multirow{2}{*}{$\begin{array}{c}\text { Hertfordshire } \\
6.44 \\
6.59\end{array}$} \\
\hline & $\left\{\begin{array}{l}1969 \\
1970\end{array}\right.$ & .. & $\because$. & & & & & & & \\
\hline & $\left\{\begin{array}{l}1969 \\
1970\end{array}\right.$ & $\because$. & $\therefore$ & $\begin{array}{l}7.99 \\
9.21\end{array}$ & $\begin{array}{l}4.87 \\
6.90\end{array}$ & $\begin{array}{r}8 \cdot 90 \\
10 \cdot 13\end{array}$ & $\begin{array}{l}8 \cdot 75 \\
9 \cdot 58\end{array}$ & $\begin{array}{l}9 \cdot 54 \\
8 \cdot 10\end{array}$ & $\begin{array}{l}5.57 \\
5.90\end{array}$ & $\begin{array}{l}6.58 \\
6.26\end{array}$ \\
\hline September & $\left\{\begin{array}{l}1969 \\
1970\end{array}\right.$ & .. & $\therefore$ & $\begin{array}{l}8.46 \\
8.37\end{array}$ & $\begin{array}{l}6.53 \\
8.28\end{array}$ & $\begin{array}{l}9.64 \\
9.01\end{array}$ & $\begin{array}{l}9.33 \\
9.92\end{array}$ & $\begin{array}{l}8.40 \\
8.75\end{array}$ & $\begin{array}{l}6 \cdot 24 \\
5 \cdot 34\end{array}$ & $\begin{array}{l}5 \cdot 22 \\
5 \cdot 35\end{array}$ \\
\hline December & $\left\{\begin{array}{l}1969 \\
1970\end{array}\right.$ & $\because$. & $\therefore$ & $\begin{array}{l}9.43 \\
8.54 \\
\end{array}$ & $\begin{array}{l}7.52 \\
6.23 \\
\end{array}$ & $\begin{array}{r}9 \cdot 30 \\
10.53 \\
\end{array}$ & $\begin{array}{l}9.93 \\
9.58 \\
\end{array}$ & $\begin{array}{l}9 \cdot 56 \\
9 \cdot 20 \\
\end{array}$ & $\begin{array}{l}5.90 \\
5.56\end{array}$ & $\begin{array}{l}6 \cdot 18 \\
6.86\end{array}$ \\
\hline \multicolumn{4}{|c|}{ Average No. of live births per quarter } & 4,700 & 1,100 & 1,300 & 2,600 & 3,100 & 1,200 & 3,600 \\
\hline
\end{tabular}

- Area covered by Oxford Record Linkage Study-that is, Oxford and Reading County Boroughs, Oxfordshire, and Berkshire (part of).

adverse effect operating in utero. A recent report of transplacental transfer of influenza virus is of particular interest in this connexion, since it appears to be the first direct evidence that influenza can infect the fetus (Yawn et al., 1971). We have sought information on the seasonal incidence of prematurity from certain local health authorities known to have readily available birth records which included birth weight and month of birth. The data obtained, based on a total of about 70,000 live births per year or about $8 \%$ of all live births in England and Wales, are summarized in Table V. In six of the seven areas the proportion of live births that were premature according to birth weight in the first quarter of 1970 was higher than in the corresponding quarter of 1969 , and in five of the seven areas the same was true of the second quarter. The variations between 1969 and 1970 shown in Table V may be reflecting longer-term trends, and more extensive data would be welcome. Nevertheless, it is evident that the proportions of premature live births tended to be higher in the first half of 1970 compared with 1969 but not in the second half. These findings are consistent with the hypothesis that the influenza epidemic was responsible for an increase in the prematurity rate. We conclude therefore that the observed increase in the national early neonatal death rate could reflect such an increase in the prematurity rate.

We have not referred to the large epidemic of 1957; indeed, we have included 1957 among the non-epidemic years. The reason for doing so is that "Asian 'flu" arrived in the late summer and the epidemic was at its height in October. So far as the first quarter was concerned, 1957 was a year remarkably free of influenza. It must be stated that a comparison of the first quarters of 1957 and 1958 fails to show any delayed effect on neonatal mortality attributable to the influenza epidemic of the previous autumn. The epidemic of 1959 was the only one during the period under review when influenza $B$ virus was widely prevalent as well as influenza $A$ (Department of Health and Social Security, 1970). Since the A and B viruses are known to differ in certain respects it is possible they could differ also in relation to early neonatal mortality.

The possibility that influenza infection of a pregnant woman might adversely affect the fetus has been considered by several investigators, but almost without exception they have sought teratogenic effects. The findings reborted have been contradictory, and on balance the evidence for such an effect is slender. In our data we could find no changes in infant mortality from congenital malformations or in stillbirth rates (of which anencephaly is a major component) which could be related to maternal exoosure to a high prevalence of influenza during the first trimester of pregnancy. Rogers (1972) came to the same conclusion.

A preoccupation with the possibility of a teratogenic effect is probably the reason why so little information bearing on other possible effects on the fetus can be gleaned from the reports in the literature. There are, nevertheless, some suggestive findings. For example, while Coffey and Jessop (1959) did not state the number of early neonatal deaths, it may be noted that in their series mothers giving a history of influenza in pregnancy had a higher proportion $(7 \cdot 5 \%)$ of babies of low birth weight than the mothers in the control group (6.6\%). Pleydell (1960) recorded one early neonatal death among the offspring of 18 mothers who had had influenza in the second trimester. In a prospective study of virus diseases in pregnancy in Great Britain (Ministry of Health, 1960) one early neonatal death occurred among the babies of 99 women who had had influenza in the second trimester. The incidence of premature birth in the series reported by Hardy et al. (1961) was higher (8.7\%) among mothers with clinical or serological evidence of influenza infection, or both, than among mothers with neither (5.6\%). McDonald (1961) found that women whose pregnancy resulted in stillbirths or neonatal death gave a history of acute febrile illness in early pregnancy more often $(8 \cdot 1 \%)$ than did women whose infants were normal $(4 \cdot 2 \%)$. There is also a suggestion in the paper by Doll et al. (1960) that influenza in pregnancy results in a tendency to low birth weight.

Taken separately, none of these findings could be regarded as conventionally significant. They all deal with relatively few pregnancies and the effect we postulate is a small one. Thus if the early neonatal death rates by quarter-years observed in 1969 had applied to the live births by quarters in 1970 the number of early neonatal deaths would have been 8,110 instead of the actual number of 8,326, a reduction of 216 deaths. Differences of the same order of magnitude were associated with the other major epidemics in the period under consideration.

Confirmation of the existence of an adverse effect of maternal influenza on the fetus might be obtained through a prospective study. That would have to be on a very large scale, enrolling perhaps 20,000 or more expectant mothers, because of the many other factors known to be associated with early neonatal death. An investigation on a smaller scale might suffice to detect a "shift to the left" in the distribution of birth weights of liveborn infants. Ideally the study should be designed to show whether the effect is specifically attributable to the influenza virus or is due to some non-specific feature of infection, such as fever, or to medication taken because of the illness.

We are indebted to Dr. R. C. Record, Professor H. Campbell, Dr. B. J. L. Moss. Dr. Kennedy Campbell, Dr. J. A. Baldwin, Dr. J. A. G. Watson, and Dr. G. W. Knight for kindly providing the data on seasonal distribution of live birth weights.

\section{References}

Coffey, V. P., and Jessop, W. J. E. (1959). Lancet, 2, 935

Department of Health and Social Security (1970). On the State of the Public Health. Annual Report of the Chief Medical Officer for the Year 1969, p. 45. London, H.M.S.O.

Department of Health and Social Security (1971). On the State of the Public Health. Annual Report of the Chief Medical Officer for the Year 1970, p. 3. London, H.M.S.O.

Doll, R., Hill, A. Bradford, and Sakula, J. (1960). British fournal of Preventive and Social Medicine, 14, 167.

Hardy, J. M. B., Azarowicz, E. N., Mannini, A., Medearis, D. N., and Cooke, R. E. (1961). American fournal of Public Health and the Nation's Health, 51, 1182 .

McDonald, A. D. (1961). British Fournal of Preventive and Social Medicine, $15,154$.

Ministry of Health (1960). Rubella and Other Virus Infections during Pregnancy. London, H.M.S.O.

Pleydell, M. J. (1960). British Medical Fournal, 1, 309.

Rogers, S. C. (1972). Lancet, 1, 261.

World Health Organization (1970). World Health Statistics Reports, 23, No. 12.

World Health Organization (1971). World Health Statistics Reports, 24, No. 9.

Yawn, D. H., Pyeatte, J. C., Joseph, J. M., Eichler, S. L., and GarciaBunuel, R. (1971). Fournal of the American Medical Association, 216, 1022. 